\title{
Amylolytic Activity in Selected Sweetpotato (Ipomoea batatas Lam) Varieties during Development and in Storage
}

\author{
Agnes Nabubuya ${ }^{1}$, Agnes Namutebi ${ }^{1}$, Yusuf Byaruhanga ${ }^{1}$ Judith Narvhus $^{2}$, Yngve Stenstrøm ${ }^{2}$, \\ Trude Wicklund ${ }^{2}$
}

${ }^{1}$ Department of Food Technology and Nutrition, Makerere University, Kampala, Uganda; ${ }^{2}$ Department of Chemistry, Biotechnology and Food Science, Norwegian University of Life Sciences, Aas, Norway.

Email: agnesnabubuya@yahoo.co.uk

Received March $8^{\text {th }}, 2012$; revised March $22^{\text {nd }}, 2012$; accepted March $31^{\text {st }}, 2012$

\begin{abstract}
Sweetpotato varieties (five) were investigated for changes in $\alpha$ - and $\beta$-amylase activities during root development and on subjection of harvested roots to different postharvest handling and storage conditions. Changes in $\alpha$ - and $\beta$-amylase activities in development were monitored from 10 weeks after planting. At physiological maturity, sweetpotato roots were harvested and subjected to various conditions: freshly harvested roots and cured roots (spread under the sun for four days at $29^{\circ} \mathrm{C}-31^{\circ} \mathrm{C}$ and $63 \%-65 \%$ relative humidity), stored at ambient conditions $\left(23^{\circ} \mathrm{C}-26^{\circ} \mathrm{C}\right.$ and $70 \%-80 \%$ relative humidity) and in a semi-underground pit $\left(19^{\circ} \mathrm{C}-21^{\circ} \mathrm{C}\right.$ and $90 \%-95 \%$ relative humidity). Generally $\alpha$ - and $\beta$-amylase activities increased during development with NASPOT 9 and 10 consistently registering the highest activities and NASPOT 1 the lowest activity. Generally, maximum $\alpha$-amylase activities were achieved at week 3 in ambient stores for NASPOT 9 and NASPOT 10 at 0.930 and $0.897 \mathrm{CU} / \mathrm{g}$, respectively. Maximum $\beta$-amylase activity was achieved in ambient stores at week 3 and 4 for fresh and cured NASPOT 9 at 806 and $782 \mathrm{BU} / \mathrm{g}$, respectively. Generally, curing and storing sweetpotatoes in ambient conditions registered the highest amylase activity. Maximum $\alpha$ - and $\beta$-amylase activities were registered at $67^{\circ} \mathrm{C}-68^{\circ} \mathrm{C}$ and $58^{\circ} \mathrm{C}-60^{\circ} \mathrm{C}$, respectively. These findings provide information for controlled modification of amylase activities of these sweetpotato varieties for product development efforts and monitoring the shelf life of the roots during storage.
\end{abstract}

Keywords: Sweetpotato; $\alpha$-Amylase; $\beta$-Amylase; Development; Postharvest Handling; Storage

\section{Introduction}

Sweetpotato (Ipomoea batatas) is an important food crop, ranks fourth among the world's most important food crops and is seventh in production worldwide [1]. The main constituents of sweetpotato dry matter are carbohydrates with starch forming $50 \%-70 \%$ [2]. Besides the high starch content, sweetpotato also contains endogenous amylases with the two major ones being $\alpha$ - and $\beta$-amylases [3,4].

The endogenous amylases have a substantial influence on sweetpotato roots in storage and during processing because they facilitate the breakdown of starch [5-7]. Beta-amylase is the most abundant constituting about 5\% of the total soluble protein of the sweetpotato root [8] and is ubiquitously distributed throughout the root. Alpha-amylase on the other hand has been shown to occur in very small quantities in the fresh roots $[9,10]$. Despite its reported low quantity in the sweetpotato root, $\alpha$ amylase has been demonstrated to be the major enzyme controlling viscosity in model starch systems. This is attributed to the fact that $\alpha$-amylase has the capacity to bind and attack raw starch producing maltose and limit dextrins [11]. Alpha-amylase has the ability to directly attack the entire starch granule releasing dextrin which is then hydrolyzed into maltose by $\beta$-amylase and $\alpha$-glucosidase $[12,13]$. Beta-amylases on the other hand are unable to hydrolyze raw sweetpotato starch but rather facilitate the breakdown of chemically solubilized or boiled starch $[14,15]$.

Several studies on amylase activity of sweetpotatoes in storage have been reported [16-18] with significant varietal differences detected in $\alpha$ - and $\beta$-amylase activi- ties. In Uganda, sweetpotato roots are subjected to a number of postharvest handling and storage conditions to prolong the life of the roots in storage. There is therefore need to evaluate the effect of the different postharvest handling and storage conditions on the activities of sweetpotato $\alpha$ and $\beta$-amylases. There are also no com- prehensive studies on the variation of amylase activity in developing sweetpotato roots although it has been re- 
ported that in apples, the levels of starch, sugars and amylase activity increase gradually to reach a maximum and subsequently reduce [19]. Studies done on tubers of Solanum tuberosum showed increment in total starch, reduction in sugars and no notable change in several enzymes in the tuber during development [20]. This study was conducted to determine the changes in $\alpha$ - and $\beta$-amylase activities of sweetpotato roots during development and in various storage conditions as well as to establish the temperature for optimal $\alpha$ - and $\beta$-amylase activity of five Ugandan varieties.

\section{Materials and Methods}

\subsection{Sweetpotato and Reagents}

Five sweetpotato varieties were used in this study and had characteristics as shown in Table 1. Four of the sweetpotato varieties are conventionally bred by the National Agriculture Crop Resource Research Institute (NACCRI) in Uganda for the farmers, whereas "Kakamega" (SPK004) originated from Kakamega in Kenya.

The reagents used were of analytical grade and were obtained from Megazyme International Ireland Ltd., Bray, C. Wicklow and Sigma-Aldrich Chemical Company.

\subsection{Experimental Method}

Sweetpotatoes were grown in three replicates under experimental conditions at the National Agriculture Crop Resource Research Institute Namulonge in Uganda. Harvesting of sweetpotato roots started in the $10^{\text {th }}$ week $(2.5$ months) with an average root weight of $50 \mathrm{~g}$. Thereafter, harvesting was done weekly to monitor variation in $\alpha$ and $\beta$ amylase activities during development of the roots up to a period of eight weeks.

At physiological maturity (3.5 months), sweetpotato roots were harvested for studies on storage. Two storage conditions were used and they included ambient (room) storage $\left(23^{\circ} \mathrm{C}-26^{\circ} \mathrm{C}\right.$ and $70 \%-80 \%$ relative humidity) and pit storage which is a storage technology developed

Table 1. Characteristics of Sweetpotato varieties used in the study.

\begin{tabular}{cccc}
\hline $\begin{array}{c}\text { Sweetpotato } \\
\text { variety }\end{array}$ & Other name (s) & $\begin{array}{c}\text { Flesh } \\
\text { colour }\end{array}$ & $\begin{array}{c}\text { Dry matter } \\
\text { content }(\%)^{*}\end{array}$ \\
\hline NASPOT 1 & & Cream & $36.3 \pm 3.07$ \\
NASPOT 2 & & White & $33.0 \pm 0.53$ \\
NASPOT 9 & SPK004/6 & Orange & $30.3 \pm 0.37$ \\
NASPOT 10 & SPKOO4/6/6 & Orange & $32.5 \pm 0.36$ \\
Kakamega & SPKOO4 & Pale orange & $34.6 \pm 0.28$ \\
\hline
\end{tabular}

*Mean values of triplicate experiments $\pm \mathrm{SD}$. for small hold farmers $\left(19^{\circ} \mathrm{C}-21^{\circ} \mathrm{C}\right.$ and $90 \%-95 \%$ relative humidity). Pit storage involved storage of the sweetpotato roots in a pit ( 2 feet deep) lined with spear grass. The sweetpotato roots that were subjected to these two storage conditions were handled in two ways; freshly harvested roots and those that were initially spread and dried under the sun for 4 days $\left(29^{\circ} \mathrm{C}-31^{\circ} \mathrm{C}\right.$ and $63 \%$ $65 \%$ relative humidity), that is cured sweetpotatoes. The roots were stored for eight weeks and analyzed weekly for changes in $\alpha$ - and $\beta$-amylase activities.

\subsection{Sample Preparation for Laboratory Analysis}

Four sound roots were randomly selected for each sweetpotato variety from each of the three replicates and used for the analyses. For the developing sweetpotatoes, the weight of the roots varied from 50 - $180 \mathrm{~g}$ over the study period, while the weight for the roots in storage was 180 $250 \mathrm{~g}$. The selected roots were washed under running water, peeled, halved longitudinally and uniformly grated. The grated tissue from the 4 roots per replicate was combined and mixed thoroughly. The grated sweetpotato was oven dried at $40^{\circ} \mathrm{C}$ for $18 \mathrm{hr}$, then milled into flour using a laboratory mill 3303, Falling number, Huddings, Sweden.

\subsubsection{Laboratory Analyses}

\subsubsection{1. $\alpha$-Amylase Activity}

Alpha-amylase activity was determined using the Ceralpha method as described [21] using kits from Megazyme International Ireland Ltd. Crude enzyme extracts were obtained by incubating $3.0 \mathrm{~g}$ of sweetpotato flour with $20.0 \mathrm{ml}$ of Buffer A (containing $1 \mathrm{M}$ sodium malate, $1 \mathrm{M}$ sodium chloride and $40 \mathrm{mM}$ calcium chloride) for 20 minutes at $40^{\circ} \mathrm{C}$. Pre-incubated enzyme extract $(0.2 \mathrm{ml})$ was then incubated with $0.2 \mathrm{ml}$ of pre-incubated substrate (p-nitrophenyl maltohepatoaside) at $40^{\circ} \mathrm{C}$ for exactly 20 minutes. The reaction was terminated by adding $3 \mathrm{ml}$ of the stopping reagent (containing 20\% tri-sodium phosphate) and the absorbance was read at $400 \mathrm{~nm}$. Alpha-amylase enzyme activity was expressed as Ceralpha Units per gram of flour (CU/g) dry weight. One unit of activity is defined as the amount of enzyme, required to release one micromole of $p$-nitrophenol from the substrate in one minute under the defined assay conditions.

\subsubsection{2. $\beta$-Amylase Activity}

Beta-amylase activity was determined using the Betamyl method as described [22] using kits from Megazyme International Ireland Ltd. A crude enzyme extract was obtained by incubating $0.5 \mathrm{~g}$ of sweetpotato flour with $5.0 \mathrm{ml}$ of Buffer A (containing $6.06 \mathrm{~g}$ trizma base, $0.37 \mathrm{~g}$ disodium EDTA, cystein and $1 \mathrm{M} \mathrm{HCl}$ ) over 1 hour period at room temperature. An aliquot of the extracted 
enzyme was diluted appropriately with buffer B (100 $\mathrm{mM}$ sodium malate solution at $\mathrm{pH}$ 6.2). Pre-incubated enzyme extract $(0.2 \mathrm{ml})$ was incubated with $0.2 \mathrm{ml}$ of pre-incubated substrate ( $p$-nitrophenyl-maltopentaoside) at $40^{\circ} \mathrm{C}$ for exactly 10 minutes. The reaction was terminated by adding $3 \mathrm{ml}$ of the stopping reagent (containing $1 \%$ trizma base) and the absorbance was read at $400 \mathrm{~nm}$. Beta-amylase activity was appropriately calculated from the absorbance values and enzyme activity was expressed as Betamyl units per gram flour (BU/g) dry weight.

2.3.1.3. $\alpha$ - and $\beta$-Amylase Activity Optimal Temperature Optimal temperatures of reaction for sweetpotato $\alpha$ - and $\beta$-amylases were determined by analyzing for $\alpha$ - and $\beta$-amylase activities using the Amylase HR assay reagent (Ceralpha method) and Betamyl kits; respectively from Megazyme International Ireland Ltd. Crude enzyme extracts $(0.2 \mathrm{ml})$ for $\alpha$ - and $\beta$-amylases were incubated in triplicate with $0.2 \mathrm{ml}$ of the respective substrates at $40^{\circ} \mathrm{C}$, $45^{\circ} \mathrm{C}, 50^{\circ} \mathrm{C}, 60^{\circ} \mathrm{C}, 65^{\circ} \mathrm{C}, 70^{\circ} \mathrm{C}, 75^{\circ} \mathrm{C}$ and $80^{\circ} \mathrm{C}$. Enzyme activity was expressed using the respective enzyme units per gram.

\subsection{Statistical Analysis}

All the samples, reactions and analyses were done in triplicates. All the data was analyzed using analysis of variance (ANOVA) and comparison of means carried out using least significant difference test (LSD) using the statistical package for Social Scientists (SPSS) version

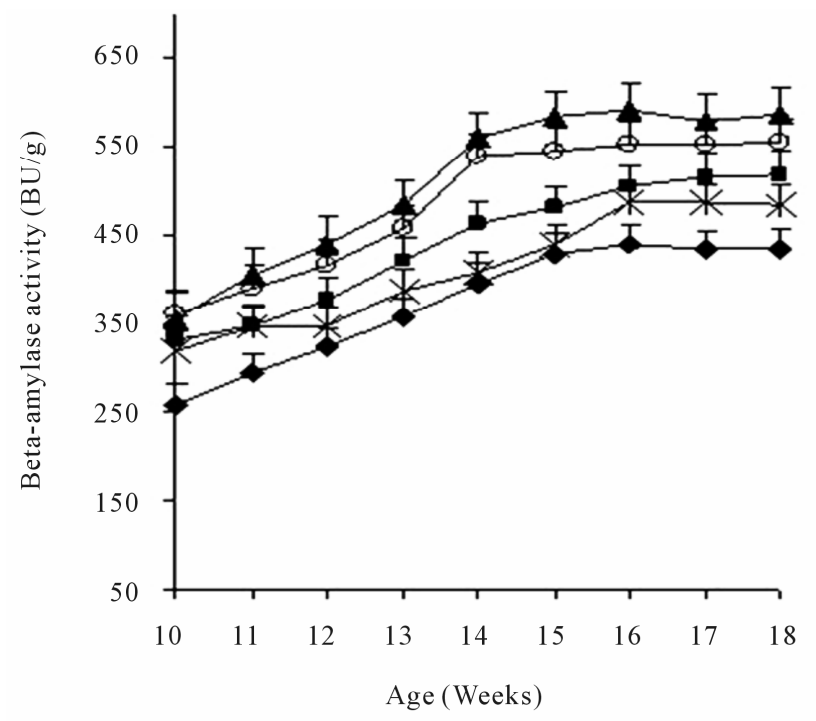

(a)
15. Significance was accepted at $\mathrm{p}<0.05$. The results are presented as means with standard errors.

\section{Results}

\subsection{Amylase Activity in Developing Sweetpotatoes}

\subsection{1. $\alpha$-Amylase Activity}

The average $\alpha$-amylase activity in the roots of the five sweetpotato varieties at harvest was $0.093 \mathrm{CU} / \mathrm{g}$. There was significant difference $(\mathrm{p}<0.05)$ in $\alpha$-amylase activity among sweetpotato varieties through the study period. Figure 1(b) shows that NASPOT 9 had the highest activity, on average $0.216 \mathrm{CU} / \mathrm{g}$ and NASPOT 1 had the lowest activity, on average $0.081 \mathrm{CU} / \mathrm{g}$ that is a three-fold difference between these varieties. During the period of development, $\alpha$-amylase activity increased gradually in all the five sweetpotato varieties. It increased continuously in four of the varieties but reduced slightly in NASPOT 9 in weeks 17 and 18. The $\alpha$-amylase activity of the five sweetpotato varieties generally doubled during the study period as can be seen in Figure 1(b).

\subsection{2. $\beta$-Amylase Activity}

The average $\beta$-amylase activity in the roots of the five sweetpotato varieties at harvest was $324.7 \mathrm{BU} / \mathrm{g}$. NASPOT 9 had the highest activity on average $508 \mathrm{BU} / \mathrm{g}$ and NASPOT 1 had the lowest activity on average $421 \mathrm{BU} / \mathrm{g}$.

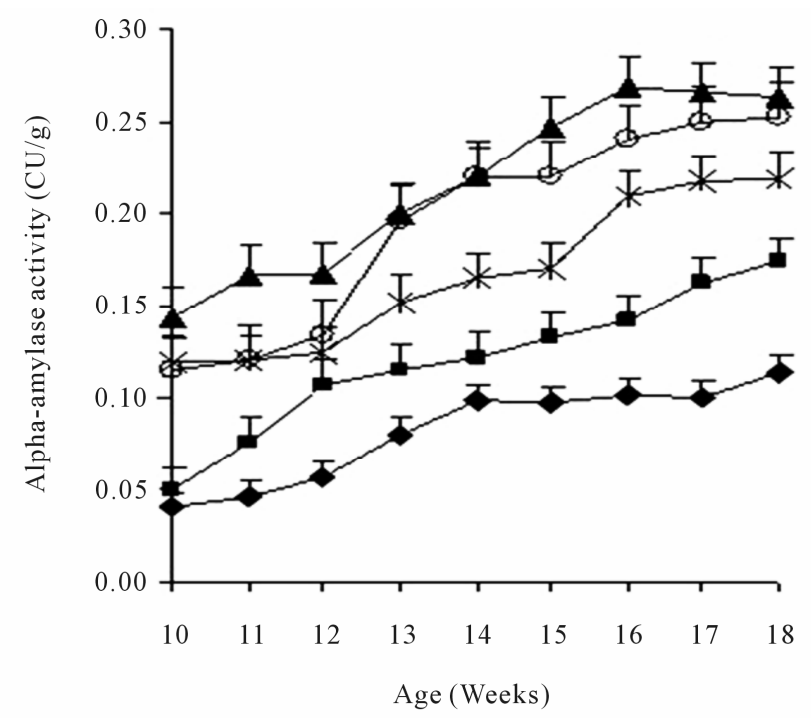

(b)

$$
\begin{array}{ll}
\longrightarrow \text { NASPOT } 1 & - \text { NASPOT } 2 \\
- \text { NASPOT } 9 & - \text { NASPOT } 10 \\
\text { N- Kakamega } &
\end{array}
$$

Figure 1. Changes in $\alpha$-and $\beta$-amylase activity in the roots of five sweetpotato varieties during development: (a) $\beta$-amylase activity, Betamyl Units per gram (BU/g); (b) $\alpha$-amylase activity, Ceralpha Units per gram (CU/g). 
During the period of development, the activity of $\beta$ amylase increased in all varieties of sweetpotato. It increased continuously in NASPOT 2 but, in the other four varieties the $\beta$-amylase activities reached their peak in weeks 14,15 , and 16 for NASPOT 10, NASPOT 9, NASPOT1 and Kakamega respectively before remaining relatively constant. The $\beta$-amylase activity was consistently highest in NASPOT 9 and lowest in NASPOT 1 as is depicted in Figure 1(a).

\subsection{Amylase Activity during Storage}

\subsection{1. $\alpha$-Amylase Activity}

The average $\alpha$-amylase activity of the five sweetpotato varieties at harvest was $0.164 \mathrm{CU} / \mathrm{g}$ and the average ac-

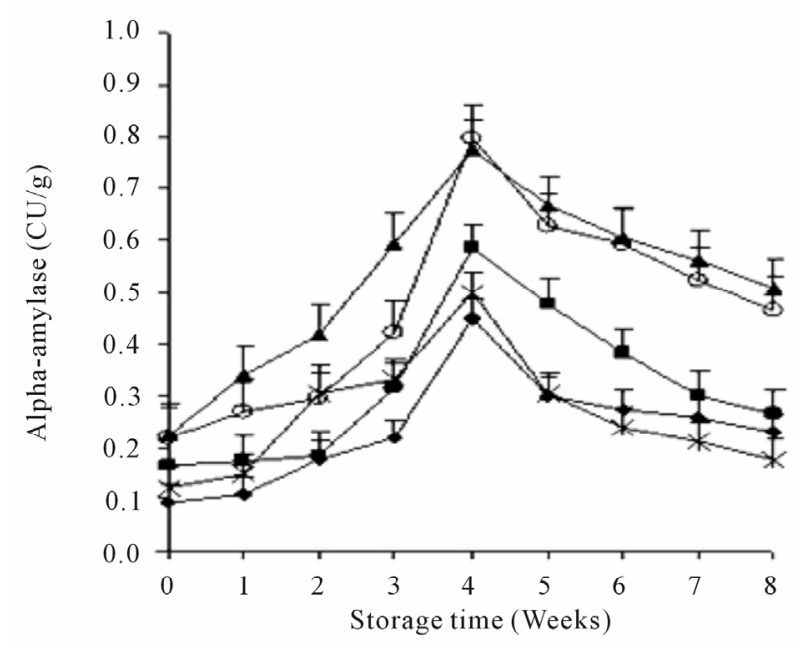

(a)

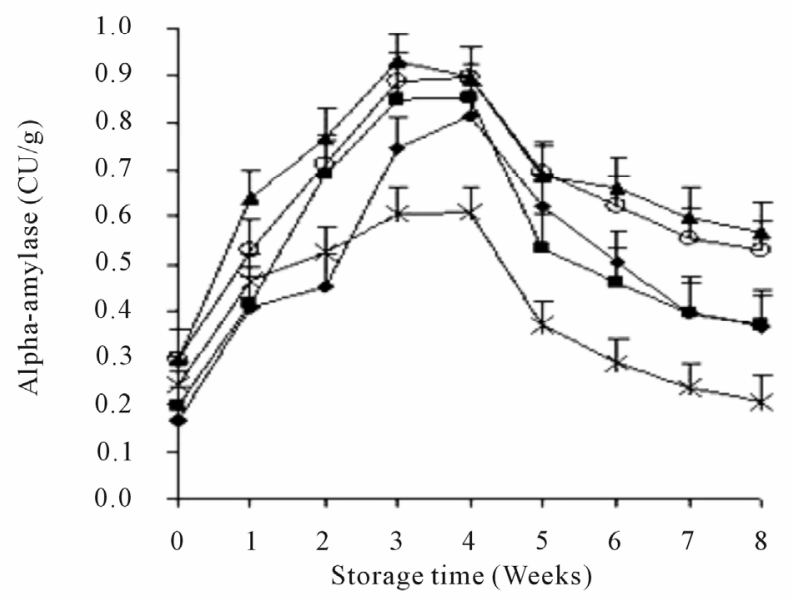

(c) tivity of $\alpha$-amylase in the roots after curing for 4 days at $29^{\circ} \mathrm{C}-31^{\circ} \mathrm{C}$ and $63 \%-65 \%$ relative humidity was 0.239 $\mathrm{CU} / \mathrm{g}$. Results obtained from both fresh and cured roots stored at ambient/room conditions and semi-ground facility (pit) showed that there were significant differences $(\mathrm{p}<0.05)$ in $\alpha$-amylase activity among sweetpotato varieties in both storage conditions as shown in Figure 2.

The $\alpha$-amylase activity was consistently higher in NASPOT 9 and NASPOT 10 than in the other three sweetpotato varieties under the two storage conditions. NASPOT 1 also had the lowest $\alpha$-amylase activity in all cases except in roots which were cured and stored under ambient/ room conditions as shown in Figure 2(c). The $\alpha$-amylase activity in all the five varieties under room and pit stor-

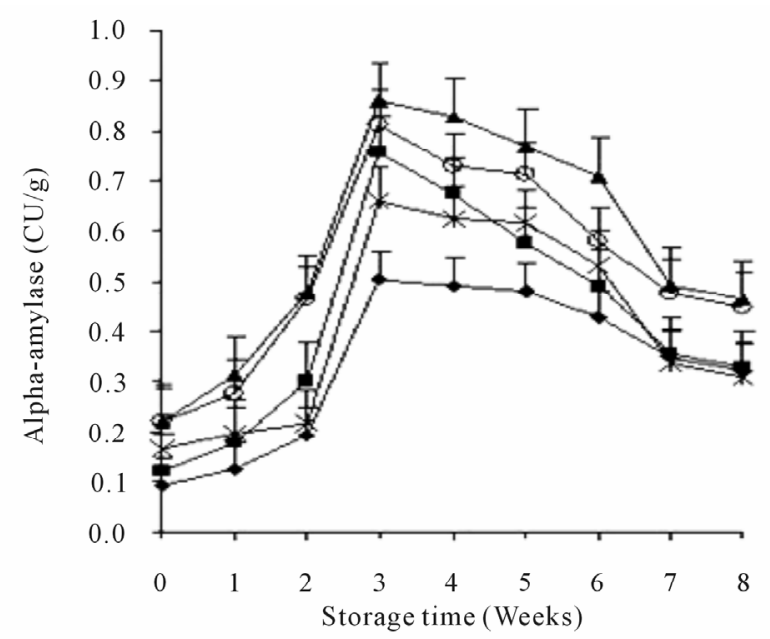

(b)

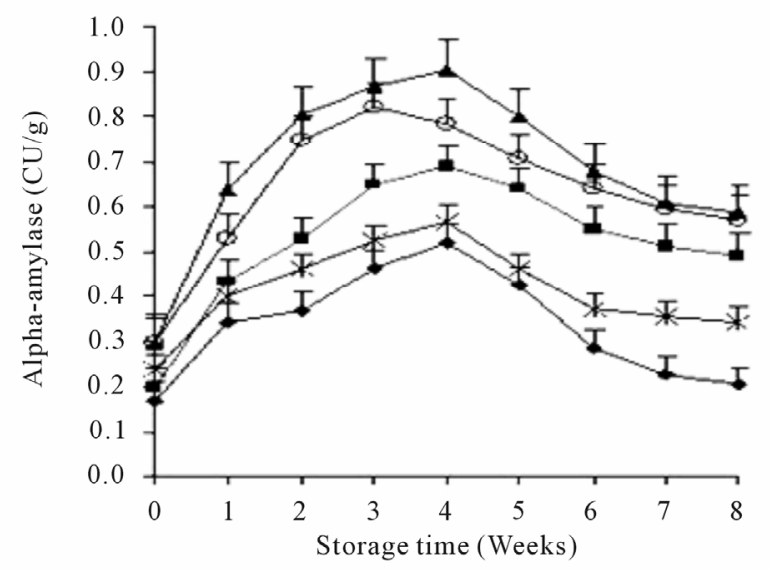

(d)
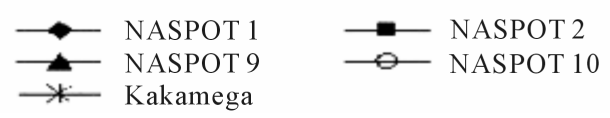

Figure 2. Changes in $\alpha$-amylase activity in the roots of five sweetpotato varieties subjected to various storage conditions: (a) Freshly harvested roots stored under room conditions $\left(23^{\circ} \mathrm{C}-26^{\circ} \mathrm{C}\right.$ and $70 \%-80 \%$ relative humidity); (b) Freshly harvested roots stored in the pit $\left(19^{\circ} \mathrm{C}-21^{\circ} \mathrm{C}\right.$ and $90 \%-95 \%$ relative humidity); (c) Cured roots stored under room conditions $\left(23^{\circ} \mathrm{C}\right.$ $26^{\circ} \mathrm{C}$ and $70 \%-80 \%$ relative humidity); (d) Cured roots stored in the pit $\left(19^{\circ} \mathrm{C}-21^{\circ} \mathrm{C}\right.$ and $90 \%-95 \%$ relative humidity). 
age varied during the storage period. Figure 2 shows that the enzyme activity increased in all the five sweetpotato varieties after harvest reached maximum (within weeks 3 and 4) and declined thereafter. The $\alpha$-amylase activity in NASPOT 1 and Kakamega varieties declined to harvest levels but, remained higher than the harvest levels for the other three varieties. Sweetpotato roots that were spread under the sun for 4 days at $29^{\circ} \mathrm{C}-31^{\circ} \mathrm{C}$ and $63 \%-65 \%$ relative humidity (cured) before storage showed on average higher initial $\alpha$-amylase activity $(0.239 \mathrm{CU} / \mathrm{g})$ compared to the freshly harvested roots $(0.164 \mathrm{CU} / \mathrm{g})$. There was however no significant difference $(p>0.05)$ in $\alpha$ amylase activity during subsequent weeks of storage between those roots which were stored directly while

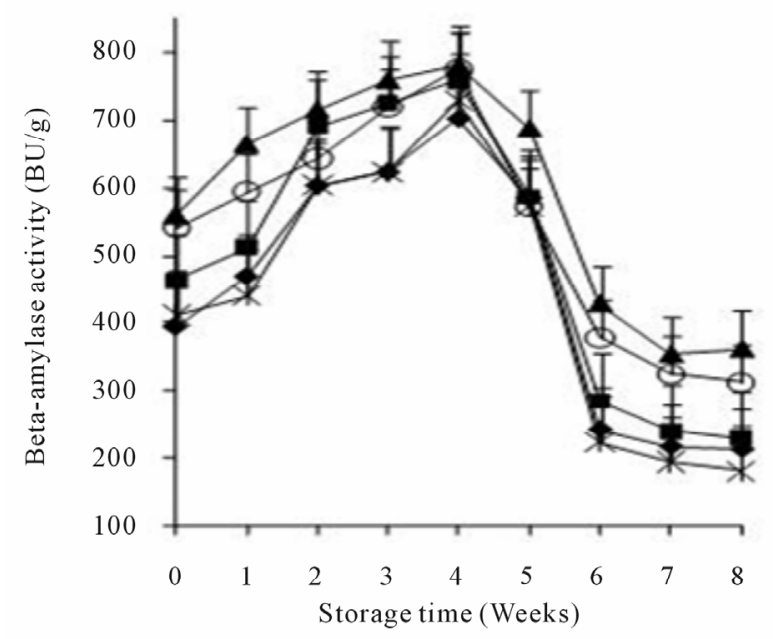

(a)

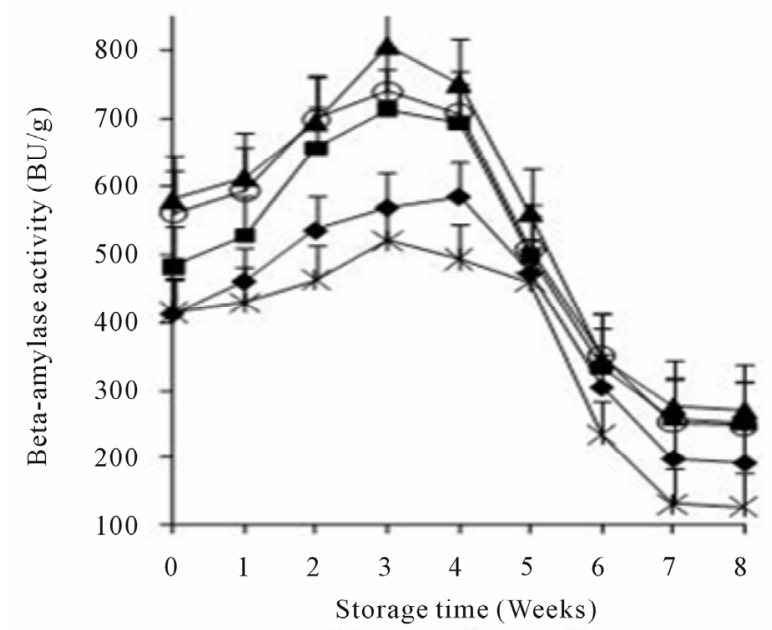

(c)

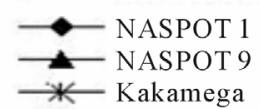

fresh and those that were cured prior to storage.

\subsubsection{Beta-Amylase Activity}

The $\beta$-amylase activity in the five sweetpotato varieties at harvest was $472.6 \mathrm{BU} / \mathrm{g}$ while the average activity of $\beta$-amylase in the in the roots after curing for 4 days at $30^{\circ} \mathrm{C}-31^{\circ} \mathrm{C}$ and $63 \%-65 \%$ relative humidity was 496.6 $\mathrm{BU} / \mathrm{g}$. Results obtained from roots that were stored while fresh from the garden and those that were cured prior to storage and stored at ambient/room conditions and semi-ground facility (pit) showed that there were significant differences $(\mathrm{p}<0.05)$ in $\beta$-amylase activity among sweetpotato varieties in both storage conditions as is observed in Figure 3. Beta-amylase activity was consis-

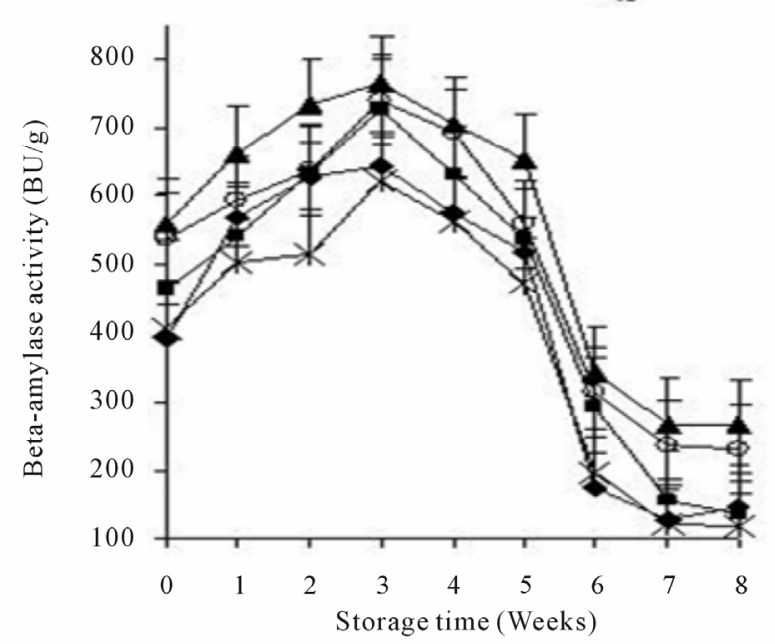

(b)

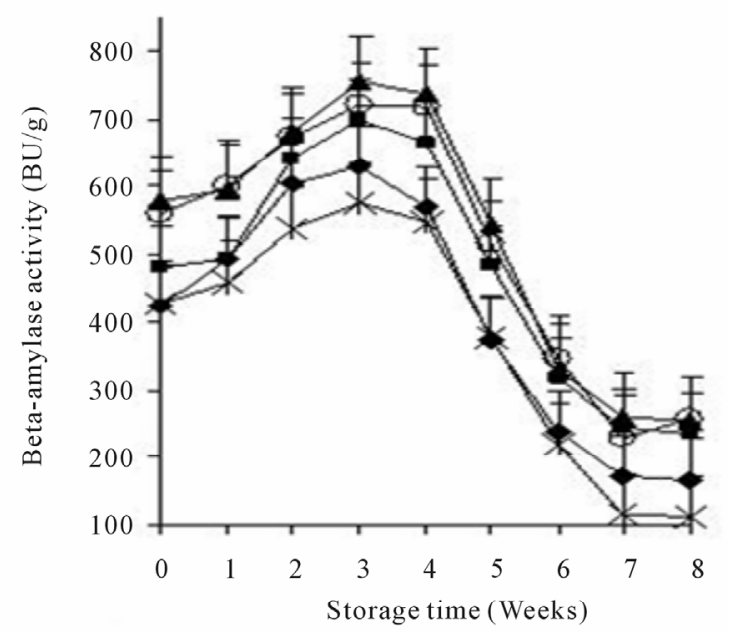

(d)

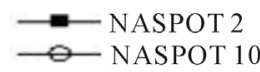

Figure 3. Changes in $\beta$-amylase activity in the roots of five sweetpotato varieties subjected to various storage conditions: (a) Freshly harvested roots stored under room conditions $\left(23^{\circ} \mathrm{C}-26^{\circ} \mathrm{C}\right.$ and $70 \%-80 \%$ relative humidity); (b) Freshly harvested roots stored in the pit $\left(19^{\circ} \mathrm{C}-21^{\circ} \mathrm{C}\right.$ and $90 \%-95 \%$ relative humidity); (c) Cured roots stored under room conditions (23 ${ }^{\circ} \mathrm{C}$ $26^{\circ} \mathrm{C}$ and $70 \%-80 \%$ relative humidity); (d) Cured roots stored in the pit $\left(19^{\circ} \mathrm{C}-21^{\circ} \mathrm{C}\right.$ and $90 \%-95 \%$ relative humidity). 
tently higher in NASPOT 9, NASPOT 10 and NASPOT 2 than in the other two sweetpotato varieties under the two storage conditions. Kakamega contained the lowest $\beta$-amylase activity in both storage conditions. There was variation in the activity of $\beta$-amylase in all the five sweetpotato varieties under both room and pit storage conditions. It can be seen in Figure 3 that the activity in all the stored roots increased after harvest, reached a maximum (within weeks 3 and 4) and declined drasticcally between weeks 4 and 6 and then remained constant. A similar trend was observed in both storage conditions for both fresh and cured roots. The $\beta$-amylase activities of all the sweetpotato varieties in both storage conditions were much lower than the activity at harvest that is a 4 -fold difference by the end of the study. Cured roots showed higher initial $\beta$-amylase activity on average (490 $\mathrm{BU} / \mathrm{g}$ ) compared to the freshly harvested roots (473 $\mathrm{BU} / \mathrm{g})$. There was however no significant difference ( $\mathrm{p}>$ $0.05)$ in $\beta$-amylase activity between the roots which were stored when fresh and those that were cured prior to storage in the subsequent weeks of storage.

\subsection{Temperature for Optimal Amylase Activity}

Figure 4 highlights the temperatures for optimal sweetpotato $\alpha$-amylase and $\beta$-amylase activities which ranged from $65^{\circ} \mathrm{C}-68^{\circ} \mathrm{C}$ and $58^{\circ} \mathrm{C}-60^{\circ} \mathrm{C}$ respectively and which corresponded to highest activity for the five sweetpotato varieties. The activities of both enzymes were gradually, and for some varieties drastically, reduced at temperatures beyond their optimal activity as shown in

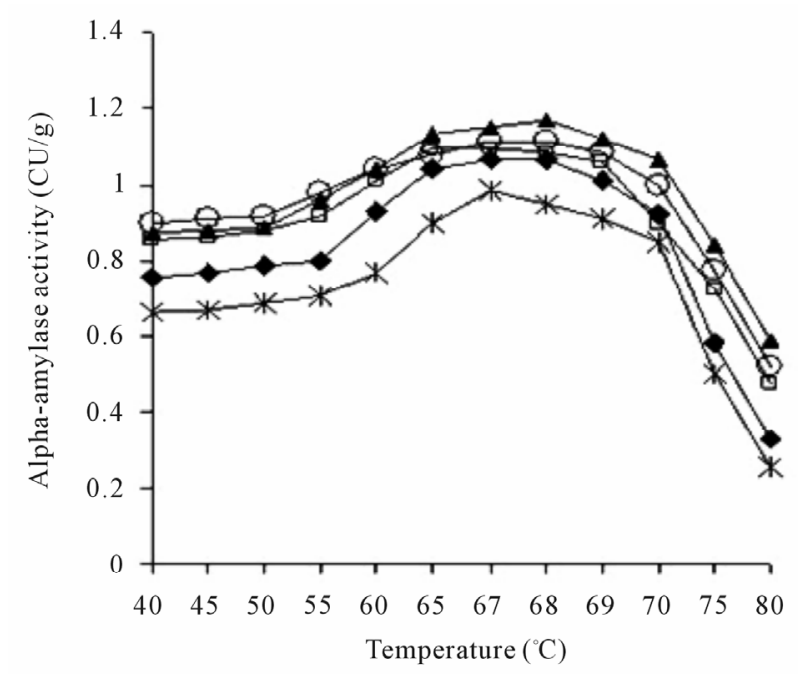

(a)
Figures 4(a) and (b). NASPOT $9\left(1.169 \mathrm{CU} / \mathrm{g}\right.$ at $\left.68^{\circ} \mathrm{C}\right)$ and NASPOT $10\left(1.117 \mathrm{CU} / \mathrm{g}\right.$ at $\left.67^{\circ} \mathrm{C}-68^{\circ} \mathrm{C}\right)$ exhibited the highest $\alpha$-amylase activity compared to the other three varieties. NASPOT 2 optimal $\alpha$-amylase activity $(1.099 \mathrm{CU} / \mathrm{g})$ was registered at $65^{\circ} \mathrm{C}$, and NASPOT1 $(1.066 \mathrm{CU} / \mathrm{g})$ and Kakamega $(0.987 \mathrm{CU} / \mathrm{g})$ at $67^{\circ} \mathrm{C}$. With respect to $\beta$-amylase activity, NASPOT $9(1389.6 \mathrm{BU} / \mathrm{g})$ and NASPOT $2(1352.8 \mathrm{BU} / \mathrm{g})$ exhibited the highest activities at $60^{\circ} \mathrm{C}$, followed by NASPOT $10(1255.7 \mathrm{BU} / \mathrm{g}$ at $\left.60^{\circ} \mathrm{C}\right)$ and NASPOT $1\left(1007.7 \mathrm{BU} / \mathrm{g}\right.$ at $\left.58^{\circ} \mathrm{C}\right)$. Kakamega exhibited the least optimal $\beta$-amylase activity $(956.6 \mathrm{BU} / \mathrm{g})$ at $58^{\circ} \mathrm{C}$.

\section{Discussion}

\subsection{Amylases in Sweetpotato Roots during Development}

Results from this study generally showed significant variations $(\mathrm{p}<0.05)$ in the $\alpha$ - and $\beta$-amylase activities among the five sweetpotato varieties. Varietal differences in $\alpha$ - and $\beta$-amylase activities were also revealed during development and storage of the roots. $\beta$-amylase is the most abundant of the amylases constituting about $5 \%$ of the total soluble protein of the tuberous root [8].

These results are in agreement with other studies showing varietal differences in $\alpha$ - and $\beta$-amylase activities in fresh and stored sweetpotato roots $[9,17,18]$. Betaamylase activity was very high compared to $\alpha$-amylase activity in all varieties during development and in storage. It is known that fresh sweetpotato roots contain very little

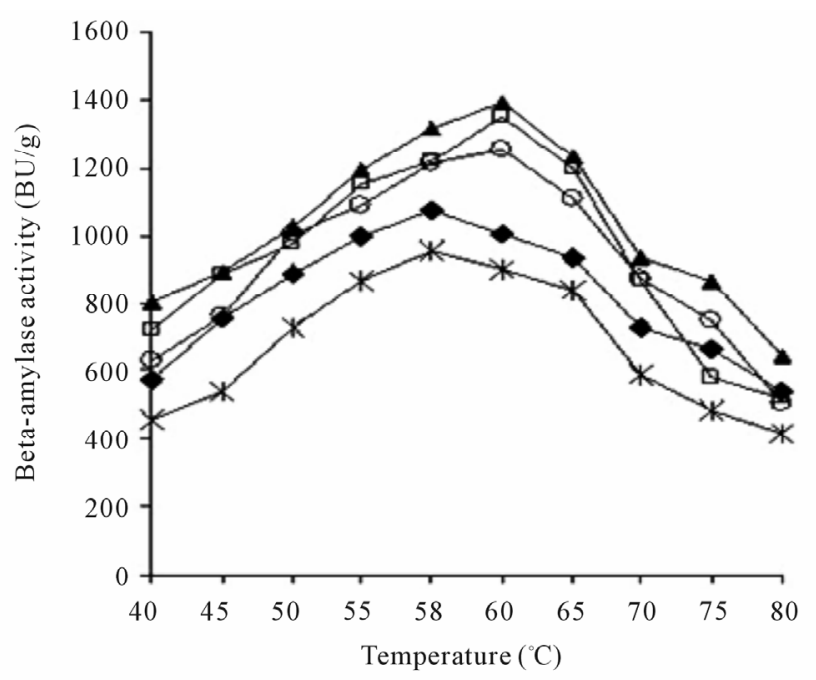

(b)
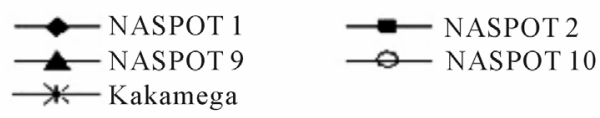

Figure 4. Optimal temperatures for sweetpotato $\alpha$ - and $\beta$-amylase activities: (a) $\alpha$-amylase activities for roots of 5 sweetpotato varieties; (b) $\beta$-amylase activities for roots of 5 sweetpotato varieties. 
$\alpha$-amylase [10] which is reported to be concentrated at the periphery of the root [9]. The $\alpha$ - and $\beta$-amylase activities in all the five sweetpotato varieties were found to be lower at early development and then increased continually during development. A similar trend in $\alpha$ - and $\beta$-amylase activities in developing apples has been documented [19]. The changes in $\beta$-amylase activity in the developing apples were attributed to increase in expression in the enzyme protein. Apple $\beta$-amylases are said to have a high degree of antigenic similarity to $\beta$-amylases from sweetpotato [19].

\subsection{Effect of Postharvest Handling and Storage Conditions on Sweetpotato Amylase Activity}

This study determined the effect of different postharvest handling conditions (fresh handling and, curing at $29^{\circ} \mathrm{C}$ $31^{\circ} \mathrm{C}$ and $63 \%-65 \% \mathrm{RH}$ ) storage conditions (room storage at $23^{\circ} \mathrm{C}-26^{\circ} \mathrm{C}$ and $70 \%-80 \% \mathrm{RH}$ and pit storage at $\left.19^{\circ} \mathrm{C}-21^{\circ} \mathrm{C}, 90 \%-95 \% \mathrm{RH}\right)$ on the $\alpha$ - and $\beta$-amylase activities of five sweetpotato varieties. Results showed increase in both $\alpha$ - and $\beta$-amylase activities for all the five sweetpotato varieties in both storage conditions up to weeks 3 and 4 of storage and then a reduction in the activities. A number of researchers have conducted studies on amylase activity in stored sweetpotato roots. One study on amylases in sweetpotato showed that $\alpha$-amylase activity in Chinese sweetpotato varieties was low at harvest, increased to higher levels after 60 days in storage (8 weeks) and reduced thereafter [18]. Another study revealed increase in $\alpha$ - and $\beta$-amylases of Porto Rico and Beauregard sweetpotato cultivars to a peak between days 13 - 22 ( 2 - 3 weeks) during germination and then a reduction in activities. Another study had reported that $\alpha$-amylase activity in sweetpotato increased to a peak after 90 days (12 weeks) in storage [16].

Results from this study were in agreement with the results from the earlier studies and revealed similar trends in both $\alpha$ - and $\beta$-amylase activities in sweetpotato roots in storage. There were however differences in the time that was required for the $\alpha$ - and $\beta$-amylase activities to reach the peak. Whereas in the earlier studies the sweetpotato roots attained peak amylase activity after 8 and 12 weeks in storage [16,18], the roots used in this study attained peak amylase activity after 3 - 4 weeks. The time taken to attain peak amylase activity in this study was similar to that observed during germination of sweetpotato roots [3]. The differences in results could be attributed to sweetpotato varieties used in the various studies and the ecological zones in which the sweetpotatoes were grown [23]. Increase in $\alpha$-amylase activity has been attributed to de novo synthesis of $\alpha$-amylase [3] and its diffusion into the starchy endosperm [24] during storage.

These results revealed that the different storage condi- tions $\left(23^{\circ} \mathrm{C}-26^{\circ} \mathrm{C}, 70 \%-80 \% \mathrm{RH}\right.$ and $19^{\circ} \mathrm{C}-21^{\circ} \mathrm{C}$, $90 \%-95 \% \mathrm{RH})$ did not significantly affect the activities of the sweetpotato $\alpha$ - and $\beta$-amylases $(\mathrm{p} \geq 0.05)$ although the activities were generally higher in room stored roots $\left(23^{\circ} \mathrm{C}-26^{\circ} \mathrm{C}, 70 \%-80 \% \mathrm{RH}\right)$. The results for $\alpha$-amylase activity in this study had a similar trend with results from tuberous-rooted chervil roots in which increase in activity was induced by storage temperatures of $10^{\circ} \mathrm{C}-16^{\circ} \mathrm{C}$ and not $4^{\circ} \mathrm{C}$ [25], although in the storage temperatures used in this study were higher. Results from a study conducted on potato had also reported low levels of $\alpha$-amylase activity in potato at low temperature [26]. The trends of $\beta$-amylase activity in storage obtained in this study were in agreement with findings of similar studies [3,9,16-18], despite the different storage conditions. These results were however not consistent with results obtained from tuberous-rooted chervil roots which indicated that $\beta$-amylase was high when stored at lower temperatures $\left(4^{\circ} \mathrm{C}\right)$ but, decreased at higher temperatures [25]. Betaamylase activity in potato has been reported by some researchers to be highly temperature sensitive, increases with lower temperature [27], although others have found that low temperature had no effect on amylase activity of potato [28].

This study has also shown that the activities of both $\alpha$ and $\beta$-amylases of sweetpotato depend on the storage conditions especially the temperature and relative humidity. Sweetpotato continue to transpire in storage as starch is being converted to sugars [29]. Amylases are responsible for the breakdown of starch in the sweetpotato [5-7,14]. It has also been documented that sweetpotato roots begin to sprout when stored at temperatures higher than $16^{\circ} \mathrm{C}$ for a long time [30] and that sprouting coincides with rise in amylase activity and breakdown of starch.

\subsection{Temperatures for Optimal Sweetpotato Amylase Activity}

Results from this study also revealed that the optimal temperatures for $\alpha$ - and $\beta$-amylases were $67^{\circ} \mathrm{C}-68^{\circ} \mathrm{C}$ and $58^{\circ} \mathrm{C}-60^{\circ} \mathrm{C}$ respectively, which concurred with published literature showing that $\alpha$-amylases have higher optimum temperature than $\beta$-amylases [3]. The study revealed that NASPOT9 (and Naspot10 in the case of $\alpha$-amylase) can be taken advantage of using its endogenous amylases to capitalize on its highest activity.

This study has demonstrated the trends in endogenous amylase ( $\alpha$ - and $\beta$-) activities that can be modulated depending on the physiological status of the sweetpotato roots. Highest activities being registered for room stored roots are shown in Figures 2 and 3. This however, has implications as a functional property, whereby endogenous amylases could be maximally taken advantage of. Secondly, in instances where there is need to slow down 
activities, prior to subsequent usage, the pit store would be the appropriate store to room (ambient) store. Generally, depending on subsequent use and desired product attribute it is therefore possible to modify the endogenous amylase activity of the roots during development and post harvest handling.

\section{Conclusions}

Results from this study revealed the effect of different postharvest handling and storage conditions on the activities of $\alpha$ - and $\beta$-amylases for five varieties and the time when peak activity of these enzymes is attained. This provides basis for the categorization of the studied sweetpotato varieties and tagging them to various uses which may include extraction of the pure enzymes for commercial use, development of sweetpotato based products depending on the desired attributes.

Increased interest in the use of sweetpotato as a raw material for processed products in the developing world makes the knowledge of the changes in chemical properties in the sweetpotato roots under different conditions a prerequisite step in the food industry. With a lot already documented on the effect of varietal differences on $\alpha$ and $\beta$-amylase activities of sweetpotato roots and the variation of these enzymes in storage, it is very important to document the changes that occur in both $\alpha$ - and $\beta$-amylase activities during development and the effects that various postharvest handling and storage conditions have on the enzymes. The study has showed that the behavior of these five sweetpotato varieties is similar in trends compared to other varieties. The study has demonstrated the potential use of each of these varieties for various alternative functions. Knowledge of these changes can facilitate the estimation of optimum growth periods and storage time for the different sweetpotato varieties in order to meet different food industry needs.

\section{Acknowledgements}

The authors wish to express their sincere thanks to the Norwegian Programme for Development, Research and Education (NUFU) for facilitating this research by providing financial support through the Norwegian University of Life Sciences (UMB) in Norway and Makerere University (MAK) in Uganda. We are also grateful to the National Crop Resource Research Institute (Namulonge) in Uganda for providing the land and human resource for growing the sweetpotatoes. We are thankful for the technical support rendered to us by Kari Olsen (UMB) and Benjamin Sentongo (MAK).

\section{REFERENCES}

[1] FAOSTAT, Statistical Database (Online) of Food and
Agriculture Organization of the United Nations, 2008.

[2] J. A. Woolfe, "Sweetpotato: An Untapped Food Resource," Cambridge University Press, Cambridge, 1992.

[3] V. Hagenimana, R. E. Simard and L. P. Vezina, "Amylolytic Activity in Germinating Sweetpotato (Ipomea batatas) Roots," Journal of the American Society of Horticultural Science, Vol. 119, No. 2, 1994, pp. 313-320.

[4] H. Li and O. Kazuko, "Major Soluble Proteins of Sweetpotato Roots and Changes in Protein after Cutting, Infection or Storage," Agriculcural and Biological Chemistry, Vol. 49, No. 3, 1985, pp. 737-744. doi:10.1271/bbb1961.49.737

[5] H. J. Deobald, V. C. Hasling and M. E. A. Catalano, "Control of Sweetpotato Alpha-Amylase for Producing Optimum Quality Precooked Dehydrated Flakes," Journal of Food Technology, Vol. 22, 1968, p. 627.

[6] M. W. Hoover and S. J. Harmon, "Changes in Sweetpotato Flakes Made by the Enzyme Activation Technique," Journal of Food Technology, Vol. 21, 1967, pp. 115-118.

[7] W. M. Walter and A. E. Purcell, "Changes in Amyloid Carbohydrates during Preparation of Sweetpotato Flakes," Journal of Food Science, Vol. 41, 1976, pp. 1374-1377. doi:10.1111/j.1365-2621.1976.tb01175.x

[8] K. Nakamura, M. Ohto and N. Yoshida, "Sucrose-Induced Accumulation of $\beta$-Amylase Occurs Concomitant with the Accumulation of Starch and Sporamin in LeafPetiole Cuttings of Sweet Potato," Plant Physiology, Vol. 96, No. 3, 1991, pp. 902-909.

doi:10.1104/pp.96.3.902

[9] V. Hagenimana, L. P. Vezina and R. E. Simard, "Distribution of Amylases within Sweetpotato (Ipomoea batatas) Root Tissues," Journal of Agriculture and Food chemistry, Vol. 40, 1992, pp. 1777-1783. doi:10.1021/if00022a010

[10] M. Ikemiya and H. J. Deobald, "New Characteristic Alpha Amylases in Sweetpotato," Journal of Agriculture and Food Chemistry, Vol. 14, 1966, p. 237. doi:10.1021/jf60145a011

[11] D. J. Manners, "Biochemistry of Storage Carbohydrates in Green Plants," In P. M. D. Dey, Ed., Academic press, London, 1985, pp. 149-203.

[12] E. Beck and P. Ziegler, "Biosynthesis and Degradation of Starch in Higher Plants," Annual Review of Plant Physiology and Plant Molecular Bioliology, Vol. 40, 1989, pp. 95-117. doi:10.1146/annurev.pp.40.060189.000523

[13] E. Sarikaya, H. Higasa and M. Adachi, "Comparison of Degradation Abilities of $\alpha$ - and $\beta$-Amylases on Raw Starch Granules," Process Biochemistry, Vol. 35, No. 7, 2000, pp. 711-715. doi:10.1016/S0032-9592(99)00133-8

[14] P. Halmer, "The Mobilization of Storage Carbohydrates in Germinated Seeds," Journal of Vegetable Physiology, Vol. 23, 1985, pp. 107-125.

[15] R. N. McArdle and J. C. Bouwkamp, "Use of Heat Treatment for Saccharification of Sweetpotato Mashes," Journal of Food Science, Vol. 51, 1986, pp. 364-366. doi:10.1111/j.1365-2621.1986.tb11131.x 
[16] T. A. Morrison, R. Pressey and S. J. Kays, "Changes in $\alpha$ and $\beta$-Amylase during Storage of Sweet Potato Lines with Varying Starch Hydrolysis," Journal of the American Society of Horticultural Science, Vol. 118, No. 2, 1993, pp. 236-242.

[17] Y. Takahata, T. Noda and T. Sato, "Carbohydrate and Enzyme Activities of Sweetpotato Line during Storage," Journal of Agriculture and Food Chemistry, Vol. 43, No. 7, 1995, pp. 1923-1928. doi:10.1021/jf00055a031

[18] Z. Zhang, C. C. Wheatley and H. Corke, "Bechemical Changes during Storage of Sweetpotato Roots Differing in Dry Matter Content," Journal of Postharvest Biology and Technology, Vol. 24, No. 3, 2002, pp. 317-325. doi:10.1016/S0925-5214(01)00149-1

[19] D. Zhang and Y. Wang, "Beta-Amylase in Developing Apple Fruits: Activities, Amounts and Sub Cellular Localization," Science in China C L, Vol. 45, No. 4, 2002, pp. 429-440.

[20] S. Morrell and T. Rees, "Sugar Metabolism in Developing Tubers of Solanum tuberosum," Phytochemistry, Vol. 23, No. 7, 1986, pp. I579-1585.

[21] B. V. McCleary, M. McNally, D. Monaghan and D. C. Mugford, "Measurement of $\alpha$-Amylase Activity in White Wheat Flour, Milled Malt and Microbial Enzyme Preparations Using Ceralpha Assay," Journal of AOAC International, Vol. 85, 2002, pp. 1096-1102.

[22] P. R. Mathewson and B. W. Seabourn, "A New Procedure for Specific Determination of Beta-Amylase in Cereals," Journal of Agriculture and Food Chemistry, Vol. 31, No. 6, 1983, pp. 1322-1326. doi:10.1021/jf00120a043

[23] N. T Dziedzoave, A. J. Graffham, A. Westby, J. Otoo and G. Komlaga, "Influence of Variety and Growth Environ- ment on Beta-Amylase Activity of Flour from Sweet Potato," Food Control, Vol. 21, No. 2, 2010, pp. 162-165. doi:10.1016/j.foodcont.2009.05.005

[24] H. Tomura and T. Koshiba, " $\alpha$-Amylase in Vigna Mungo Cotyledon,” Plant Physiology, Vol. 79, 1985, pp. 939-942. doi:10.1104/pp.79.4.939

[25] E. Geoffriau, A. Suel, M. Briard, J. Y. Péron and O. J. Ayala Garay, "Evolution of Amylase Activity in Tuberous-Rooted Chervil (Chaerophyllum bulbosum L) Roots during Storage at Various Temperature," Acta Horticulturae (ISHS), Vol. 682, 2005, pp. 153-1158.

[26] T. H. Nielsen, U. Deiting and M. Stitt, "Beta-Amylase in Potato Tubers Is Induced during Storage at Low Temperatures," Plant Physiology, Vol. 113, No. 2, 1997, pp. 503-510.

[27] J. E. Cottrell, C. M. Duffus, L. Paterson, G. R. Mackey, M. J. Allison and H. Bain, "The Effect of Storage Temperature on Reducing Sugar Concentration and Activities of Three Amylotic Enzymes in Tubers of Cultivated Potato, Solanum tuberosum," Potato Research, Vol. 36, 1993, pp. 107-117. doi:10.1007/BF02358725

[28] J. R. Sowokinos, E. C. Lulai and J. A. Knoper, "Translucent Tissue Defects in Solanum tuberosum L. I Alteration in Amyloplast Memberane Integrity, Enzyme Activities, Sugars and Starch Content," Plant Physiology, Vol. 78, 1985, pp. 489-494. doi:10.1104/pp.78.3.489

[29] V. D. Truong, R. Y. Avula, K. Pecota and C. G. Yencho, "Sweetpotatoes," Wiley-Blackwell, Hoboken, 2011.

[30] B. Edmunds, M. Boyette, C. Clark, D. Ferrin, T. Smith and G. Holmes, "Postharvest Handling of Sweetpotatoes," 2008. 